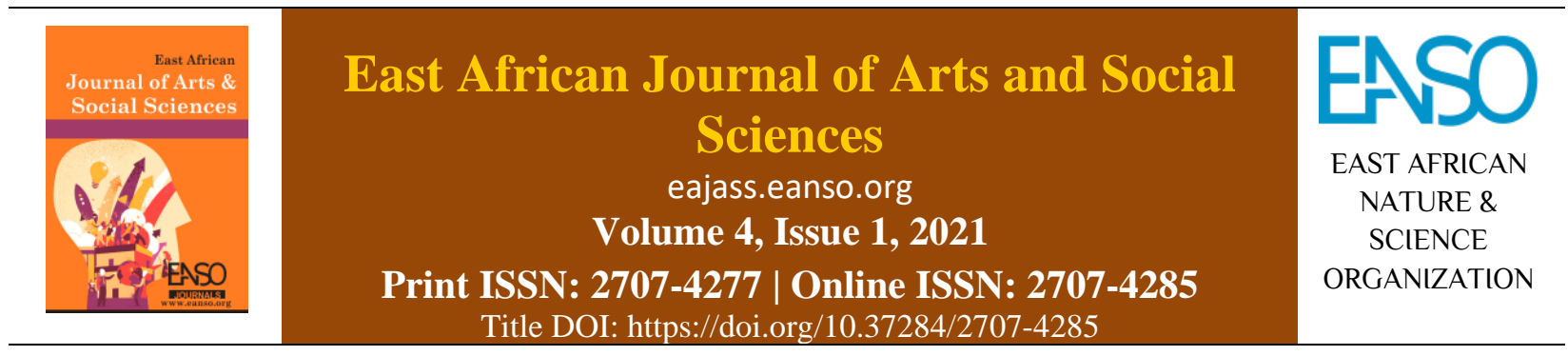

Original Article

\title{
Juvenile Delinquency and Crime Nairobi Slum Areas, Kenya.
}

\author{
Dr. John Ndikaru wa Teresia, $P h D^{1^{*}}$ \\ ${ }^{1}$ Department of Criminology and Legal Studies, The Technical University of Kenya, P. O. Box 57173 - 00200, Nairobi, Kenya. \\ *Correspondence email: jndikaru@gmail.com.
}

Article DOI: https://doi.org/10.37284/eajass.4.1.449

\section{Article history: ABSTRACT}

26 October 2021 Juvenile delinquency has become an urgent concern for sociologists across the globe because it is a significant predictor of a possible increase in criminal activity

Keywords: among our growing population. A juvenile is a person who is under the age of ordinary criminal prosecution, which is normally 17 years. The increase in the

Unrest, incidence of juvenile delinquency implies that if measures are not taken in place, Juvenile, there are possibilities of the situation running out of hand. Juvenile delinquency

Youth,

Violence,

Parenting, can be considered as social maladjustment on the part of individuals to some difficult circumstances or conditions. The descriptive research design was adopted

Community, for this study since the researcher was interested in describing the salient traits of

Criminal, young offenders in the slum areas in Nairobi County and more specifically the

Mugging, predictors of their criminal behaviour and its effects. A sample of 200 respondents

Burglary, aged 18-45 years was generated using simple random sampling. A questionnaire

Delinquency,

Offender,

Robbery,

Pickpocketing was distributed amongst the respondents. Some questionnaires were distributed virtually using the Survey Monkey platform, which enabled the respondents to access and respond to the questions using their smartphones. The descriptive statistical analysis method was used to analyse the data, which was subsequently presented in table format.

\section{APA CITATION}

wa Teresia, J. N. (2021). “Juvenile Delinquency and Crime Nairobi Slum Areas, Kenya. East African Journal of Arts and Social 4(1), 22-38. https://doi.org/10.37284/eajass.4.1.449

\section{CHICAGO CITATION}

wa Teresia, John Ndikaru. 2021. "Juvenile Delinquency and Crime Nairobi Slum Areas, Kenya". East African Journal of Arts and Social Sciences 4 (1), 22-38. https://doi.org/10.37284/eajass.4.1.449

\section{HARVARD CITATION}

wa Teresia, J. N. (2021) "Juvenile Delinquency and Crime Nairobi Slum Areas, Kenya”, East African Journal of Arts and Social Sciences, 4(1), pp. 22-38. doi: 10.37284/eajass.4.1.449.

22 | This work is licensed under a Creative Commons Attribution 4.0 International License. 
IEEE CITATION

J. N. wa Teresia, “Juvenile Delinquency and Crime Nairobi Slum Areas, Kenya”, EAJASS, vol. 4, no. 1, pp. 22-38, Oct 2021.

\section{MLA CITATION}

wa Teresia, John Ndikaru. "Juvenile Delinquency and Crime Nairobi Slum Areas, Kenya". East African Journal of Arts and Social Sciences, Vol. 4, no. 1, Oct 2021, pp. 22-38, doi:10.37284/eajass.4.1.448.

\section{INTRODUCTION}

The rapid population growth in Kenya in the recent past has resulted in the increased marginalisation of the youth in social and economic development. Currently, about $80 \%$ of the population of Kenya comprises people who are aged below 35 years. This has resulted in a corresponding increase in the number of youths who are being convicted by the criminal justice system (Omboto et al., 2013). Therefore, despite being the majority, the youth are largely relegated to the periphery of the public sphere when it comes to addressing the various social and economic issues that affect them (Mwanjala, 2015). Due to this, most young people are either underemployed or unemployed, a factor that predisposes them to endemic poverty (Mwanza, Mwaeke \& Omboto, 2020). The other factors that complicate the prospects of the youth in the country include weak and unresponsive systems of education and training which do not prepare them adequately for the challenges in the labour market. A combination of these factors makes the juveniles and youth increasingly vulnerable to crime and criminal activities (Thuku, 2017).

About $57 \%$ of criminal activities that are reported by the Kenya police are committed by the youth. There is a marked increase in the number of youth criminal gangs in the country, with most of them emerging in the slum areas in cities and towns (Wambugu, Njoroge \& Komen, 2015). Essentially, the increase in the incidence of youth crime across the country is a matter of critical concern to the general public and, more particularly, the security agencies (Mwanza, Mwaeke \& Omboto, 2020).

Some of the key criminal activities for which juveniles and young people are normally arrested include manslaughter, muggings, drug possession, assault, and theft. They commit these criminal activities using weapons such as knives, machetes, and guns. The key motivation for committing these crimes is to get the money they can use to satisfy their various needs (Omboto et al., 2013). This reflects the inability of the systems in the country to provide the youth with legitimate mechanisms for meeting their needs or other financial obligations. It also reflects an emergent generation of youth who are finding criminal activities as an attractive alternative to legitimate economic activity (Wambugu, Njoroge \& Komen, 2015).

\section{EMPIRICAL LITERATURE}

\section{Predictors of Juvenile Delinquency and Crime}

There are various factors that make it difficult for individual children to mentally and physically adapt to these conditions, thereby triggering delinquency (Muiya, 2014). Rahman (2015) argues that every juvenile offence that is committed is a product of complex causes, some of which can be traced back long before the offence was committed, while others can be directly linked to the act of delinquency. Rahman (2015) further notes that there are different sets of factors that come into play in each individual case and it is not possible to point out the group of causes that results in a particular juvenile offence. If anything, the fact is that turn the behaviour of a child to a particular direction rather than the other can be very obscure, with most of them still outside the detection of expert sociologists.

Despite the diversity and complexity of the causes of delinquency, some factors cut across most juvenile delinquency cases. The different combination of these particular factors is attributed to the differences in the juvenile offences committed (Wambugu, Njoroge \& Komen, 2015). This makes it possible for sociologists to come up with a list of factors that predict juvenile offence, which is essentially a diagnostic aid for the workers in the juvenile delinquency field (Mwanza, Mwaeke $\&$ Omboto, 2020). The predictors of youth involvement in crime can be considered as falling under categories such as individual factors, social factors, and community factors. Each of these categories is further divided into subcategories such 
as home conditions, peer-related risk factors, family risk factors, etc. (Thuku, 2017).

\section{Individual Factors Predicting Youth Involvement in Crime}

Some individual factors that predict youth involvement in criminal activity are traced back to complications in the prenatal and perinatal developmental stages of young people. Previous studies have established that about $80 \%$ of young violent offenders had experienced delivery complications as compared to 47 percent of nonoffenders (Wambugu, Njoroge \& Komen, 2015).

Other studies have demonstrated that mothers who smoked during pregnancy predisposed their children to behavioural disorders that manifested in the form of juvenile delinquency during their formative years (Muiya, 2014). The evidence in regards to these individual factors is however conflicting and has continuously warranted for further studies to be conducted on the same to comprehensively link the individual factors to juvenile delinquency (Mwanza, Mwaeke \& Omboto, 2020).

Thuku (2017) argues that other individual factors that have contributed to youth involvement in criminal activity include the inability for individuals to delay gratification, low educational aspiration, and achievement, which manifests in terms of truants who are highly likely to become offenders. Rwengo (2017) associated delayed language development and low verbal intelligence quotient with juvenile delinquency. Besides, individuals experiencing low commitment to school and low academic performance are highly likely to become child delinquents.

\section{Social Factors Predicting Youth Involvement in Crime}

The social factors that predict criminal involvement among young people include family structures and peer influence. Wanjeri (2018) notes that family structures such as family size, antisocial parenting, poor parenting skills, domestic violence, and home discord are linked to youth involvement in criminal activities. Muiya (2014) found that parental conflict, punitive discipline, and poor parental supervision have pushed young people to rebellion, which has manifested in the form of involvement in criminal activity. Wambugu, Njoroge and Komen (2015) concur that the level of parental supervision, the methods that parents used to discipline their children, parental neglect or abuse, and the quality of the relationship between parents and children are significant determinants of involvement in criminal activity by young people.

Riechi (2019) noted that the peer pressure for deviance, peer approval of delinquent behaviour, and excessive leisure time spent with peers who are delinquent invariably exposed young people to offending behaviour as a way of fitting in. Mwanza, Mwaeke and Omboto (2020) established that youth who spend most of their leisure time with peers who disapprove of delinquent behaviour is highly unlikely to engage in offending behaviour. This demonstrates the significant influence of peers and their acceptance or discouragement of delinquent behaviour and that this particular relationship is normally amplified in cases where the youth have less connection or interactions with their parents or guardians.

Kariuki-Githinji (2020) argues that there is a correlation between juvenile delinquency and lowincome families or communities. This is evident considering that juvenile delinquents are normally concentrated in particular areas of every city, which are incidentally low-income residential areas or rather the slum areas. These areas are characterised by overcrowding and deficient recreational facilities and are often close to the Central Business District of the city. The juvenile delinquency areas are highly associated with low income and high poverty levels, which are the alternatives to young people for solving their problems using criminal avenues.

Thuku (2017) argues that low income is not the key decisive factor for the adoption of juvenile delinquency behaviour; it is rather one of the many underlying factors that trigger juvenile delinquency. However, low income is directly related to impoverished family life and the insufficient provisions that young people require for wholesome development and recreation. Rwengo (2017) concurs that some of the factors that have resulted in spiralling juvenile delinquency cases include trust in his family situation and unstable families. Other factors that have contributed to juvenile 
delinquency and youth unrest include responsible media, domestic violence and abuse, urban culture, and economic stress.

According to Mwanza, Mwaeke and Omboto (2020) the family remains one of the key social dimensions that is important in understanding juvenile delinquency and youth unrest in Kenya. Most cases of indiscipline are being handled at the domestic level by parents, guardians, and school administrators.

\section{Community Factors Predicting Youth Involvement in Crime}

The community factors that predict the involvement of young people in criminal activity include school policies and the home condition or rather neighbourhood conditions. Wanjeri (2018) noted that school administrations have the responsibility of providing environments in which delinquent behaviour is discouraged among the youth. However, school administration should ensure that there is a healthy balance between discipline and the reinforcement of morally acceptable behaviour among the youth. This is because the expansion or suspension of errant youth does not necessarily produce undesirable behaviour but rather leads to increased delinquent behaviour. Young people should be provided with incentives to adopt moral behaviour since severe punishment structures have proved counterproductive in terms of resulting in an increased incidence of misbehaviour.

The neighbourhood environment in which youth are brought up is critical in influencing delinquent behaviour. There is a strong correlation between the environment in which the youth reside and their participation in criminal activities. In particular, disorganised neighbourhoods are characterised by weak social control networks, which result in isolation among some residents and also high residential turnover, which is a perfect environment for criminal activities to thrive (Mwanza, Mwaeke \& Omboto, 2020). Wambugu, Njoroge and Komen (2015) found that disorganised slum life is characterised by overcrowded households, the dilapidation of the physical infrastructure, and high residential mobility. These environs have populations that predispose young people to delinquent friends who pressure them, directly or indirectly, to get involved in criminal activities.

Various home conditions have been attributed to the occurrence of juvenile delinquency cases. KariukiGithinji (2020) acknowledges that home conditions contribute to juvenile delinquency. These are characterised by unsanitary conditions, broken homes, poverty and unemployment, material deficiencies, and immoral and delinquent parents. The other home conditions include mistreatment by parents, the stigma of legitimacy, lack of parental affection and care, and mistreatment by guardians or stepparents. Though there is a perception that parents of young people are responsible for the belligerent behaviour of their children, the decisions that young offenders make cannot be adequately understood without taking into consideration the wider social context within which they live and act.

These home conditions are closely related to neighbourhood conditions. Rahman (2015) points out that some of these neighbourhood conditions include congested neighbourhoods, the presence of gangs and gang codes, lack of recreational facilities. The other neighbourhood conditions include deplorable morality in the community, lack of social outlet, loneliness, and easy access to drugs and guns.

There are also school conditions that have triggered cases of juvenile delinquency. Rwengo (2017) notes that such school conditions include a lack of strictness by the administration which encourages students to adopt delinquent behaviours such as stealing, bullying, and abusing drugs. Besides, school administrations that are inelastic and rigid also encourage young persons to rebel by adopting delinquent behaviour. Furthermore, inadequate facilities for recreation in schools is another predictor of juvenile delinquency. Occupational conditions have also played a significant role in encouraging juvenile delinquent behaviour. Riechi (2019) concurs that such occupational conditions include regular occupation, truancy, and discipline in apprenticeship systems, occupational misfits, and idleness.

The rebellion to authorities either at home or school is another predictor of youth and juvenile delinquency. Other youths get into criminal involvement due to peer pressure and the need to fit 
in some group that they consider cool to belong to (Thuku, 2017). Access to drugs and subsequent addiction has been a key motivator of criminal activity among many young people. Youths get involved in criminal activity under the influence of drugs such as bang and chang'aa, which are easily sourced in their neighbourhoods (Rwengo, 2017).

Low family income and large family size are some of the characteristics that are associated with young offenders. The poor upbringing by guardians or parents at the critical stage of childhood predisposes children to criminal tendencies particularly when they are forced to fend for themselves for their basic needs (Omboto et al., 2013). Rapid technological advancements, individualism, and family break-ups have pushed youth to commit some forms of crime either out of excitement or as a necessary way of fending for themselves. There are games that you indulge in as they pursue excitement which leads to appalling crimes such as grievous bodily harm and vandalism (Mwanza, Mwaeke \& Omboto, 2020).

\section{METHODOLOGY}

The descriptive research design was adopted for this study since the researcher was interested in describing the salient traits of young offenders in the slum areas in Nairobi County and more specifically the predictors of their criminal behaviour and its effects.
A sample of 200 respondents aged 18-45 years was generated using simple random sampling. Questionnaires were distributed amongst the respondents. The descriptive statistical analysis method was used to analyse the data, which was subsequently presented in table format.

\section{RESULTS AND DISCUSSION}

\section{Demographics of the Respondents}

The respondents were required to indicate various aspects of their demographics. The findings showed that the respondents were almost evenly distributed based on gender with 53\% (male) and 47\% (female). About $43 \%$ of the respondents were aged between 25-44 years; $33 \%$ were aged between 1824 years, while $15 \%$ were aged between $35-44$ years (see Table 1).

Besides, $49 \%$ of the respondents were married, $43 \%$ were not married, while $8 \%$ were either divorced, separated or widowed. In terms of education, $23 \%$ had attained primary education, $30 \%$ had completed secondary education, while $15 \%$ had completed tertiary education (see Table 1). This indicated high literacy levels amongst the slum youth.

Table 1: Gender, Age, Marital Status and Education of the Respondents

\begin{tabular}{lll}
\hline Demography Attribute & \% of total Respondents \\
\hline Gender & Male & $53 \%$ \\
& Female & $47 \%$ \\
\hline Age & $18-24$ Years & $33 \%$ \\
& $25-34$ Years & $43 \%$ \\
& $35-44$ Years & $15 \%$ \\
\hline Marital Status & Married & $49 \%$ \\
& Unmarried & $43 \%$ \\
& Divorced /Separated/Widowed & $8 \%$ \\
\hline Education & Primary Level & $23 \%$ \\
& Secondary Level & $30 \%$ \\
& Tertiary Level & $15 \%$ \\
\hline
\end{tabular}

The findings indicated that most of the respondents were casual labourers (31\%) and self-employed $(23 \%)$. About $25 \%$ of the respondents were unemployed, $10 \%$ were fully employed in the formal sector, while $8 \%$ were partially employed in the same sector (see Table 2). Besides, about $47 \%$ of the respondents were leaders/breadwinners of 
their households, $24 \%$ were housewives, $7 \%$ were children, and $12 \%$ were relatives.

Most households had 3 members (27\%); $26 \%$ had 2 members; $25 \%$ had 4 members and $8 \%$ had five members and more. Most of the respondents had lived in the slums for more than 6 years $(47 \%)$, while about $27 \%$ had lived there for not more than 3 years, and $20 \%$ had lived there for a duration between $4-6$ years (see Table 2).

Table 2: Employment Status, Household Membership and Duration of Living in Slums

\begin{tabular}{lll}
\hline Factors & & \% of total Respondents \\
\hline Employment Status & Formal Fully Employment & $10 \%$ \\
& Formal Partial Employment & $8 \%$ \\
& Unemployed & $25 \%$ \\
& Self-Employed & $23 \%$ \\
& Casual Laborers & $31 \%$ \\
\hline Household Membership & Leader/Breadwinner & $47 \%$ \\
& House Wives & $24 \%$ \\
& Children & $7 \%$ \\
& Relatives & $12 \%$ \\
\hline Household Size & 2 Members & $26 \%$ \\
& 3 Members & $27 \%$ \\
& 4 Members & $25 \%$ \\
& 5 and Above Members & $8 \%$ \\
\hline Duration of Living in The Slums & $1-3$ Years & $27 \%$ \\
& $4-6$ Years & $20 \%$ \\
& Over 6 Years & $47 \%$ \\
\hline
\end{tabular}

The findings showed that most of the respondents were Christian - Protestants (50\%); about $41 \%$ were Christian - Catholics; $5 \%$ were Muslims, while 2\% claimed that they were atheists. About $41 \%$ of the respondents were fluent Kiswahili and English speakers; $47 \%$ were fluent Kiswahili speakers, while $13 \%$ could only speak Kiswahili (see Table 3).
The findings also showed that most of the slum dwellers were Luo (27\%); Kikuyus were 25\%; Luhyas and Kambas were $15 \%$ each, and Kisiis were $7 \%$. The Nubians were $2 \%$ and were only found at Kibera. Luos were the majority in Kibera (35\%) and Korogocho (37\%); Kikuyus were the majority in Mathare (40\%); while the Kamba were the majority in Mukuru (27\%) (see Table 3).

Table 3: Religion, National Languages and Ethnicity of the Respondents

\begin{tabular}{lll}
\hline Factors & & \% of total Respondents \\
\hline Religion & Christian - Catholics & $41 \%$ \\
& Christian - Protestants & $50 \%$ \\
& Muslims & $5 \%$ \\
& Atheists & $2 \%$ \\
\hline National Languages & Fluent Kiswahili & $47 \%$ \\
& English and Kiswahili & $41 \%$ \\
& Kiswahili Only & $13 \%$ \\
\hline Ethnicity & Kikuyu & $25 \%$ \\
& Luo & $27 \%$ \\
& Luhya & $15 \%$ \\
& Kamba & $15 \%$
\end{tabular}

27 | This work is licensed under a Creative Commons Attribution 4.0 International License. 
East African Journal of Arts and Social Sciences, Volume 4, Issue 1, 2021

Article DOI: https://doi.org/10.37284/eajass.4.1.449

\begin{tabular}{|c|c|c|c|c|c|}
\hline \multirow{3}{*}{ Factors } & & \multicolumn{4}{|c|}{ \% of total Respondents } \\
\hline & Kisii & $7 \%$ & & & \\
\hline & Nubian & $2 \%$ & & & \\
\hline \multirow[t]{7}{*}{ Ethnicity Vs Slum } & & Kibera & Mathare & Mukuru & Korogocho \\
\hline & Kikuyu & - & $40 \%$ & - & $33 \%$ \\
\hline & Luo & $35 \%$ & $23 \%$ & $22 \%$ & $37 \%$ \\
\hline & Luhya & $21 \%$ & - & $16 \%$ & - \\
\hline & Kamba & - & - & $27 \%$ & - \\
\hline & Kisii & $7 \%$ & - & $15 \%$ & - \\
\hline & Nubian & $2 \%$ & - & - & - \\
\hline
\end{tabular}

Social-Political Issues and Activities in the Slums

The respondents' social activities included listening to the radio (84\%), going to church or mosque $(70 \%)$, visiting friends and relatives $(68 \%)$, reading newspapers or magazines $(36 \%)$ and watching television (20\%). The most listened to radio stations included Kameme FM (19\%), Easy FM (19\%), Citizen Radio (16\%) and Kiss 100 (12|\%). The most-watched television station amongst the respondents was KTN (39\%), NTV (24\%) and KBC $(10 \%)$. About $45 \%$ of the respondents were affiliated with NASA. $20 \%$ with the Jubilee Party, $10 \%$ with AMANI, while $22 \%$ were affiliated with other smaller parties (see Table 4).

Table 4: Social-Political Issues and Activities in the Slums

\begin{tabular}{lll}
\hline Socio-Political Issues \& Activities & \% of total Respondents \\
\hline Issues \& Activities & Listening to Radio & $84 \%$ \\
& Going to Church/Mosque & $70 \%$ \\
& Visiting Friends \& Relatives & $68 \%$ \\
& Reading Newspapers/Magazines & $36 \%$ \\
& Watching Television & $20 \%$ \\
\hline Favourite Radio Stations & Citizen Radio & $16 \%$ \\
& Kiss 100 & $12 \%$ \\
& Metro FM & $8 \%$ \\
& KBC & $7 \%$ \\
& Classic 105 & $6 \%$ \\
& Ramogi FM & $6 \%$ \\
& Easy FM & $19 \%$ \\
& Kameme FM & $19 \%$ \\
\hline Favourite Television Stations & Citizen TV & $8 \%$ \\
& KTN & $39 \%$ \\
& NTV & $24 \%$ \\
& KBC & $10 \%$ \\
& Other smaller TV Stations & $6 \%$ \\
\hline Political Affiliations & JUBILEE PARTY & $20 \%$ \\
& NASA & $45 \%$ \\
& AMANI & $10 \%$ \\
& KANU & $3 \%$ \\
& Other Parties & $22 \%$ \\
\hline
\end{tabular}

28 | This work is licensed under a Creative Commons Attribution 4.0 International License. 
Economic Issues and Activities of Nairobi Slum Dwellers

The findings showed that some of the most common belongings amongst the respondents included radios (93\%), sofa sets (64\%), mosquitoes nets (57\%), and bicycles (10\%). The most predominant mode of lighting was electricity (85\%), while $18 \%$ used wick lamps and $15 \%$ used tin lamps (see Table 5). In terms of sanitation, most used pit latrines $(85 \%)$, about $14 \%$ used water closets, whereas $93 \%$ shared the toilet facilities. Most of the respondents lived in iron sheet houses (33\%), about 31\% lived in mud houses, $20 \%$ lived in brick and stone houses, while $5 \%$ lived in timber houses. Besides, most respondents earned below Ksh. 5000 per month; 19\% earned between Ksh. 5000 and Ksh. 7000, while 5\% earned more than Ksh. 9000 (see Table 5).

\section{Table 5: Economic Issues and Activities of Nairobi Slum Dwellers}

\begin{tabular}{lll}
\hline Economic Issues and Activities & \% of total Respondents \\
\hline Household Belongings & Radio & $93 \%$ \\
& Sofa set & $64 \%$ \\
& Mosquito nets & $57 \%$ \\
& Bicycles & $10 \%$ \\
\hline Lighting & Electricity & $85 \%$ \\
& Wick Lamp & $18 \%$ \\
& Tin Lamp & $15 \%$ \\
\hline Sanitation & Pit Latrine & $85 \%$ \\
& Water Closet & $14 \%$ \\
& Shared Toilet Facilities & $93 \%$ \\
\hline Types of Houses & Mud Houses & $31 \%$ \\
& Timber & $5 \%$ \\
& Brick/Stone & $20 \%$ \\
& Iron Sheet & $33 \%$ \\
\hline Monthly Income & Below Ksh. 5000 & $43 \%$ \\
& Between Ksh. 5000 - Ksh. 7000 & $19 \%$ \\
& Ksh. 9 000 Above & $5 \%$ \\
\hline
\end{tabular}

Problem Issues that Affect Slum Residents in Nairobi Metropolitan City

The study survey identified various issues which posed major challenges among the slum residents in Nairobi, chief among them health, education, economy, unemployment, poverty, politics,

Table 6: Problem issues that affect Slum Residents in Nairobi Metropolitan City

\begin{tabular}{|c|c|c|c|c|c|}
\hline & $\begin{array}{l}\text { Big } \\
\text { Problem }\end{array}$ & $\begin{array}{l}\text { Moderate } \\
\text { Problem }\end{array}$ & $\begin{array}{l}\text { Small } \\
\text { Problem }\end{array}$ & $\begin{array}{ll}\text { No } & \text { Problem at } \\
\text { All } & \end{array}$ & Refused \\
\hline Health Issues & $52 \%$ & $27 \%$ & $9 \%$ & $11 \%$ & - \\
\hline Education & $43 \%$ & $36 \%$ & $12 \%$ & $9 \%$ & - \\
\hline Economy & $81 \%$ & $14 \%$ & $3 \%$ & - & - \\
\hline Unemployment & $89 \%$ & $7 \%$ & $2 \%$ & - & - \\
\hline Politics & $14 \%$ & $17 \%$ & $35 \%$ & $32 \%$ & - \\
\hline Environment & $69 \%$ & $24 \%$ & $15 \%$ & - & - \\
\hline
\end{tabular}


East African Journal of Arts and Social Sciences, Volume 4, Issue 1, 2021

Article DOI: https://doi.org/10.37284/eajass.4.1.449

\begin{tabular}{|c|c|c|c|c|c|}
\hline & $\begin{array}{l}\text { Big } \\
\text { Problem }\end{array}$ & $\begin{array}{l}\text { Moderate } \\
\text { Problem }\end{array}$ & $\begin{array}{l}\text { Small } \\
\text { Problem }\end{array}$ & $\begin{array}{ll}\text { No } & \text { Problem } \\
\text { All } & \end{array}$ & Refused \\
\hline Poverty & $83 \%$ & $13 \%$ & - & - & - \\
\hline Crime & $47 \%$ & $35 \%$ & - & - & - \\
\hline
\end{tabular}

\section{Issues of Concern to Slum Residents of Nairobi} Metropolitan City

The findings indicated that $64 \%$ of the respondents

to clean water, and 5\% were not sure. Most respondents claimed that the sanitation in the slum was bad (82\%), only $12 \%$ claimed that it was good, while $2 \%$ were not sure (see Table 7 ).

had access to clean water, $31 \%$ did not have access

Table 7: Issues of concern to Slum Residents of Nairobi Metropolitan City

\begin{tabular}{lll}
\hline Issues of concern & & \% of total Respondents \\
\hline Access to Clean Water & Yes & $64 \%$ \\
& No & $31 \%$ \\
& Not Sure & $5 \%$ \\
\hline State of Sanitation & Good & $12 \%$ \\
& Bad & $82 \%$ \\
& Not Sure & $2 \%$ \\
\hline
\end{tabular}

The slum dwellers were concerned about the durability of their housing premises according to $78 \%$ of the respondents. Another $75 \%$ of the respondents the housing space they occupied was not adequate for their daily activities. Again, another $76 \%$ of the slum residents were fearful that they were likely to face eviction from their residence any time.

Different Nature, Typology and Causes of Slum Juvenile Delinquency and Youth Unrest in Nairobi Metropolitan City

The study findings revealed that there were crimes faced in the slums of Nairobi were categorised into two typologies: spontaneous and provoked. With little variations in the different slums of Kibera,
Mathare, Mukuru, and Korogocho, general robbery (59\%), mugging $(50 \%)$, burglary $(50 \%)$, illicit brews $(47 \%)$, assault $(43 \%)$, drugs $(31 \%)$, robbery with violence $(30 \%)$, murder $(23 \%)$, pickpocketing $(22 \%)$, and arson were experienced by slum dwellers according to the percentage of respondents indicated in brackets (see Table 8). The views of both male and female respondents were generally with slight differences with Kibera and Korogocho reporting higher male crime percentages across the crime spectrum compared to Mukuru and Mathare which reported higher cases of crimes across the board by female respondents across the entire crime typology.

Table 8: Criminal activities and prompted crimes reported in slums areas

\begin{tabular}{lll}
\hline & & \% of total Respondents \\
\hline & General robbery & $59 \%$ \\
Mugging & $50 \%$ \\
Burglary & $50 \%)$ \\
Criminal Activities & Illicit brews & $47 \%$ \\
& Assault & $43 \%$ \\
& Drugs & $31 \%$ \\
& Robbery with violence & $30 \%$ \\
& Murder & $23 \%$
\end{tabular}

30 This work is licensed under a Creative Commons Attribution 4.0 International License. 


\begin{tabular}{lll}
\hline & & \% of total Respondents \\
\hline & Pickpocketing & $22 \%$ \\
\hline & General robbery & $13 \%$ \\
& Mugging & $34 \%$ \\
& Burglary & $34 \%$ \\
Prompted Crimes Reported & Illicit brews & $50 \%$ \\
& Assault & $37 \%$ \\
& Drugs & $51 \%$ \\
& Robbery with violence & $32 \%$ \\
& Murder & $42 \%$ \\
& Pickpocketing & $32 \%$ \\
\hline
\end{tabular}

Prompted crimes reported in the slums were in the form of drugs (51\%), illicit brew (50\%), murder $(42 \%)$, assault $(37 \%)$, mugging $(34 \%)$, burglary (34\%), robbery with violence (32\%), pickpocketing $(32 \%)$, general robbery $(31 \%)$, sexual abuse $(24 \%)$, and arson (16\%) (see Table 8). Similar figures were reported in the individual slum areas of Kibera, Mathare, Mukuru and Korogocho.

When the spontaneous and provoked types were combined, the percentages of crimes reported as per the respondents increased with illicit brews $(97 \%)$ topping the charts, general robbery (90\%), burglary (85\%), mugging (84\%), drugs (82\%), assault (79\%), murder $(65 \%)$, robbery with violence $(62 \%)$, and pick-pocketing (54\%) (see Table 9). Similar statistics were reported in slum estates near industrial areas like Mukuru Kwa Njenga and Kayaba in Nairobi. Interestingly, illicit brews topped the charts in all the slums, notably as reported by $100 \%$ of respondents in Mathare.

Table 9: Spontaneous, Provoked and Prevalence of Crimes Reported

\begin{tabular}{|c|c|c|}
\hline & & $\%$ of total Respondents \\
\hline \multirow{9}{*}{$\begin{array}{l}\text { Spontaneous } \\
\text { Reported }\end{array}$} & General robbery & $90 \%$ \\
\hline & Mugging & $84 \%$ \\
\hline & Burglary & $85 \%$ \\
\hline & Illicit brews & $97 \%$ \\
\hline & Assault & $79 \%$ \\
\hline & Drugs & $82 \%$ \\
\hline & Robbery with violence & $62 \%$ \\
\hline & Murder & $65 \%$ \\
\hline & Pickpocketing & $54 \%$ \\
\hline \multirow{7}{*}{ Prevalence of Crimes in Nairobi Slums } & General robbery & $19 \%$ \\
\hline & Mugging & $18 \%$ \\
\hline & Burglary & $12 \%$ \\
\hline & Illicit brews & $26 \%$ \\
\hline & Assault & $6 \%$ \\
\hline & Drugs & $4 \%$ \\
\hline & Robbery with violence & $6 \%$ \\
\hline
\end{tabular}

The study findings revealed that the most prevalent crime was illicit brews (26\%), general robbery $(19 \%)$, mugging $(18 \%)$, burglary $(12 \%)$, assault $(6 \%)$, robbery with violence $(6 \%)$, and drugs $(4 \%)$ (see Table 9).
The fear of crime and its effects on the residents of slums in Nairobi was reported by the respondents in all the slums surveyed by the study with Kibera residents asserting that they feared crime a great deal by $67 \%$ of them, followed by Korogocho

31 This work is licensed under a Creative Commons Attribution 4.0 International License. 
(56\%), Mukuru (51\%) and lastly Mathare (47\%). Overall, $57 \%$ of the slum respondents feared crime a great deal, $25 \%$ a fair amount, and $14 \%$ not very much. Opinion was divided on the extent of crime trend perceptions with $31 \%$ of respondents stating that crime rates had increased while $46 \%$ were of the view that the rates had actually gone down. Another $18 \%$ felt that crime rates had remained the same in the past year.

While $29 \%$ of the respondents expected crime rates to increase in the next year another $42 \%$ expected a decrease in the vices with another $8 \%$ being neutral on the same issue. In the past year, $44 \%$ of respondents experienced one form of crime or another. Again, $49 \%$ of respondents experienced crime once, $24 \%$ two times, $11 \%$ three times, and $15 \%$ more than three times in the past one year in all the slums polled in the survey (see Table 10). Overall, $37 \%$ of respondents experienced crime in the last 3 months, $21 \%$ in the last 6 months, $24 \%$ in the last one year and $17 \%$ over one year ago (see Table 10).

Table 10: Projection of Crime Rates and Crime Experience

\begin{tabular}{lll}
\hline & & \% of total Respondents \\
\hline Projection of Crime Rates in the & Increase & $29 \%$ \\
Next 1 Year & Decrease & $42 \%$ \\
& Neutral & $8 \%$ \\
\hline Respondents' Experience of Crime & One form of crime of another & $44 \%$ \\
in the Past 1 Year & Experienced Once & $49 \%$ \\
& Experienced Twice & $24 \%$ \\
& Experienced Thrice & $11 \%$ \\
& More than thrice & $15 \%$ \\
\hline
\end{tabular}

On the timing of the criminal activities, the respondents viewed early night (29\%), evening $(19 \%)$, late at night $(13 \%)$, early morning (13\%), mid-morning (7\%), mid-day (7\%), and late afternoon $(7 \%)$ as the time when the crime was most prevalent in their area of residence in Nairobi (see Table 11). On the way to work, shop, place of worship and school was the most likely place of crime according to $39 \%$ of respondents, in the house $(31 \%)$, within the vicinity of the house $(19 \%)$ and at a public place $(8 \%)$. The number of attackers ranged from one according to $6 \%$ of respondents, two $(16 \%)$, three $(23 \%)$, and more than three $(29 \%)$ (see Table 11).

Table 11: Timing of Criminal Activities and Likely Place for Crime to Occur

\begin{tabular}{ll}
\hline & \% of total Respondents \\
\hline Timing of Criminal Activities & \\
\hline Early night & $29 \%$ \\
Evening & $42 \%$ \\
Late at night & $13 \%$ \\
Early morning & $13 \%$ \\
Mid-morning & $7 \%$ \\
Mid-day & $7 \%$ \\
Late afternoon & $7 \%$ \\
\hline Likely Place for Crime to Occur & \\
\hline On the way to work, shop, place of worship and school & $39 \%$ \\
In the house & $31 \%$ \\
Within the vicinity of the house & $19 \%$ \\
At a public place & $8 \%$ \\
\hline
\end{tabular}


The number of attackers ranged from one according to $6 \%$ of respondents, two $(16 \%)$, three $(23 \%)$, and more than three (29\%). About $65 \%$ of the respondents in all the slum areas in the survey reported the use of weaponry by the attackers. The types of weapons were guns/pistols according to $41 \%$ of respondents, machetes/swords (39\%), clubs $(13 \%)$, and axes $(6 \%)$. About $36 \%$ of respondents recognised the attackers who were mostly young, according to $52 \%$ of the respondents, middle age

Table 12: The Number and Knowledge of Attackers
$(42 \%)$ and a mixture of different age groups (4\%) (see Table 12).

The attackers were males in the majority of cases $(84 \%)$, female $(4 \%)$ and a mixture of the two genders $(4 \%)$. The respondents knew that the criminals were from the neighbourhood in the slum they lived in, according to $59 \%$ of them were from other slum areas $(27 \%)$, while others were not sure (24\%) (see Table 12).

\begin{tabular}{lll}
\hline & & \% of total Respondents \\
\hline Number of Attackers & One (1) & $6 \%$ \\
& Two (2) & $16 \%$ \\
& Three (3) & $23 \%$ \\
& More than Three (3) & $29 \%$ \\
\hline Knowledge of the Attackers & Attackers lived in neighbourhood & $59 \%$ \\
& Attackers lived in other slums & $27 \%$ \\
& Not sure & $24 \%$ \\
\hline
\end{tabular}

\section{Causes and Perceptions of Criminal Activities by} Nairobi Slum Residents

The study found that crime was a big problem in the slums according to $79 \%$ of the respondents due to lack of government action to mitigate the problem with another $48 \%$ perceiving an increase in crime rates in the last year. There was a general concern among the slum respondents on the status of crime in their areas of residence in the slums of Nairobi according to $74 \%$ of them.

Among other factors, the causes of crime in the slums were the extreme poverty levels according to $88 \%$ of the respondents in the survey. The study finding concluded that these poverty levels where over $60 \%$ of the slum residents earned less than Kshs 7,000 per month contributed to the alarming crime rates in the slums of Nairobi. The poverty levels experienced in the slums were a result of the dire state of the economy of people living in the slums who were unanimous in their view that the economy was a major problem. Coupled with these, the study found that education standards in the slums were declining with many children dropping out of school. The same dropouts will be members of criminal gangs later in life.
Low education standards within the slum areas were found to contribute towards the high rates of juvenile delinquency and youth unrest because of the high dropout rates among the school-going children. $76 \%$ of the respondents polled in the study were of the view that education was a big problem among the slum dwellers. When children drop out of school, their future prospects of making honest and meaningful economic contributions to Kenyan society as employees and entrepreneurs are drastically diminished. Most of them end up joining the ranks of gangsters in the slums whose main preoccupation is to steal and rob slum residents of their hard-earned meagre resources.

Unemployment was found by the study to be a major contributor to the high rates of criminal activities in the slums of Nairobi according to $89 \%$ of the respondents. The same sentiments were expressed by the respondents in the slum areas of Kibera, Mathare, Mukuru, and Korogocho in Nairobi.

The environment was found by the study to be another factor that causes the increased rates of crime according to $69 \%$ of the respondents. This was mainly because of the lack of economic opportunities in the slums of Nairobi so that 
residents are wallowing in vicious poverty, which causes them to lack money to educate their children who then do not get an opportunity to escape the poverty. The cycle then repeats itself. All the above issues of unemployment, poverty and the poor state of the economy in the slums of Nairobi have led to juvenile delinquency and various criminal activities in the slums according to the respondents.

\section{Effects of Juvenile Delinquency and Youth Unrest in the Slum Communities}

The findings revealed that women and children suffer most from criminal activities in the slums because of juvenile delinquents and youth unrest. Chief among the results of crime include cases of rape involving and the girl-child. Another harmful effect of crime was found to be the loss of household goods such as food items and electronics which normally would make life bearable within the slums. Cases of murder involving the breadwinners in the slum households would deny children and women a steady source of income and social wellbeing. The growing up of children without father figures and mentors further resulted in a new generation of young criminals with high juvenile delinquent and youthful unrest tendencies.

Illicit brews in the slums have rendered a significant number of households in the slums drunkards so that they are not able to contribute meaningfully towards the socio-economic well-being of their families. Over $97 \%$ of the respondents polled in the study confirmed that illicit brews were a major menace in the slum areas they live in with the young men unable to maintain families and the family units breaking up. The social problems associated with illicit brews included prostitution and single-parent households. The resultant challenges included poor health facing such families, low education standards and even high infant and child mortality because of problems of malnutrition and other poverty diseases.

Arson involving the burning of houses in the slums has rendered many families destitute without a roof over their heads, thereby complicating their lives even further. You can imagine life in the slums very harsh within slums under normal circumstances, but lack of housing would cause environmental diseases such as pneumonia, cholera and typhoid, which are fatal among the slum poor. Such problems are further made worse by the low levels of income and poor hygienic conditions in the slums. In other studies, within global jurisdictions, the effects of juvenile delinquency have been documented.

\section{Juvenile Delinquency and Youth Unrest Remedial Measures and Police involvement}

The study found that tackling crime in the slum areas of Nairobi required a multiplicity of approaches chief among the citizens' own conviction of making their own contribution towards fighting crimes modelled along with the ten households [Nyumba Kumi] initiative by the Kenya jubilee administration. This view was supported by $88 \%$ of the respondents in the study.

The aim is for the slum residents to be their brother's keepers by knowing their neighbours and keeping vigil $24 / 7$ on the goings-on within the vicinity of the slum estates. In support of these efforts, $75 \%$ of the respondents recommended that the slum communities should get organised in fighting crimes in the slum estates.

Apart from that, the involvement of law enforcement agencies such as the police was found to be another major avenue of fighting criminal activities. Criminal activities in the slums, by and large, went unreported according to $73 \%$ of respondents. However, the police found out about crime in various ways with personal reporting by the victims according to $59 \%$ of cases, reporting by another household member (15\%), some unknown persons called the police $(10 \%)$, and the police came to crime scene themselves (8\%). While $34 \%$ of respondents did not report cases to the police because they feared that they would not act, $31 \%$ did not have any proof of the criminal activity, $17 \%$ feared that the police would demand a bribe, while another $11 \%$ felt that the case was trivial and did not warrant police involvement.

The Kenyan police idea of tackling crime in the slums of Kibera, Mathare, Mukuru and Korogocho involved random visits according to $44 \%$ of the respondents, daily patrols of likely crime prevalent areas $(33 \%)$, and police visits after criminal activity reporting $(30 \%)$. 
Table 13: Crime Reporting and Tackling Crime by the Police

\begin{tabular}{ll}
\hline & \% of total Respondents \\
\hline Crime Reporting & \\
\hline Personal Reporting & $59 \%$ \\
Reporting by another member & $15 \%$ \\
Some unknown persons called the police & $10 \%$ \\
The police came to crime scene themselves & $8 \%$ \\
\hline Tackling Crime by Police & \\
\hline Random Visit & $44 \%$ \\
Daily Patrols & $33 \%$ \\
Police visits after criminal activity reporting & $30 \%$ \\
\hline
\end{tabular}

The study found that in the past year, police involvement in criminal activity had increased according to $35 \%$ of respondents, $34 \%$ felt that police involvement had remained the same, while another $22 \%$ were of the view that police involvement in criminal activities had generally reduced.

Overall, $68 \%$ of the respondents polled in the study were generally dissatisfied with how the Kenyan police tacked crime in their areas of residence. Only $25 \%$ of the respondents were satisfied with police handling of crime, with another $6 \%$ being noncommittal on the issue. Despite this state of approval of police work, $71 \%$ of the respondents said that there were likely to report new criminal cases to the same police as they had no other alternatives. $29 \%$ of the respondents, however, had given up on the Kenyan police as far as a criminal matter in their areas of residence was concerned.

The study respondents overwhelmingly (96\%) supported the idea that the police and the slum communities should come together and combine efforts in fighting criminal activities which came as a result of juvenile delinquent behaviour and youth unrests in the slums of Nairobi. However, the respondents $(81 \%)$ were taken aback by the problem of poor judgments by the Kenyan courts who wrongfully acquitted known juvenile delinquents and youth engaged in unrests in the slums of Nairobi. Such developments demoralised the slum community members and even the police in arresting the criminal offenders.

The entire government of Kenya has rated averagely on the level of commitment in solving crime in the slums, with $28 \%$ stating government indeed was committed to a large extent, $34 \%$ to a lesser extent, while another $34 \%$ felt that the government was committed to a small extent. Overall, $46 \%$ of the respondents felt safe in the slums, while $30 \%$ were of the view that living in the slums of Nairobi was a big security risk. Another $22 \%$ were neutral on the issue of safety in the slum areas of Nairobi. The study then concluded that insecurity in the slums of Kibera, Mathare, Mukuru and Korogocho was part of the major problems people in these areas face on a daily basis.

The study findings concluded that there was the need to initiate crime prevention mechanisms such as police patrols, vigilante groups, employed night guards, village security committees, the use of gates and fences, among other measures. An overwhelming $78 \%$ of the respondents supported these recommendations.

\section{Summary of Research Findings}

The study commenced with a definition of a juvenile delinquent in Kenya as a person who is typically under the age of 17 and commits an act that otherwise would have been charged as a crime if they were an adult. Juvenile delinquencies were categorised by the study into three categories: delinquency, criminal behaviour, and status offences.

The factors which contributed to youth delinquent crimes included individual risk factors, and family environment and peer pressure. In order to prevent juvenile delinquency, the studies suggested prevention services that included activities such as substance abuse education and treatment, family 
counselling, youth mentoring, parenting education, educational support, and youth sheltering.

The study was able to define unrest as a restless mind or state of mental disturbance caused by the continued non-achievement of expectations of youth. Violence attributed to youth unrest was categorised by the study into three broad categories: self-directed violence, interpersonal violence and collective violence.

The effects of youth unrest included juvenile murders, suicides, homicides, and rapes, destruction of property, child and elder maltreatment and intimate partner violence all of which sometimes had serious lifelong injury health consequences. Victims of youth unrest engaged in high-risk behaviours such as alcohol and substance misuse, smoking, and unsafe sex, which in turn can contribute to cardiovascular disorders, cancers, depression, diabetes and HIV/AIDS, resulting in premature death.

Among the strategies used to fight youth, unrest included the provision of childcare giver relationships, life skills in youth, egalitarian service delivery in basic necessities, positive cultural norms, support programmes for the youth, and other preventive measures such as the promotion of a supportive home environment with a view to increasing the capacity of parents and/or caregivers to raise nonviolent youth.

The study is a practical sample survey based on the slum's juvenile delinquency and youth unrest analysis of the slums in Nairobi, Kenya. The research objectives and research questions included the need to identify the differential nature, typology, and causes of slums juvenile delinquency and youth unrest in the slums of Nairobi, Kenya and a description of the prevention and control needs of the slum's juvenile delinquency and youth unrest in the slums of Nairobi, Kenya.

The study was done on a statistical sample of 659 residents of Nairobi Metropolitan slums of Kibera, Mathare, Mukuru, and Korogocho with a gender distribution of $53 \%$ males and $47 \%$ females with an age distribution of between 18 and 44 years of age.

The study identified various issues of concern that face slum dwellers, among them the extreme cases of poverty levels with the majority of slum residents earning incomes of less than Kshs 7,000 per month, the poor state of their economy, the low standards of education, falling health services and facilities, the high infant mortalities, the poor state of the surrounding environment, the very unhygienic sanitation standards, the very low quality of building materials of their housing, the very low incomes of Nairobi slum residents all of which contribute to a very meagre and basic subsistence lifestyle among the slum communities in Nairobi Metropolitan City.

\section{CONCLUSIONS}

The study findings concluded that juvenile delinquency and cases of youth unrest were quite rampant in the slums of Nairobi leading to a multiplicity of criminal activities, among them indulgence in illicit brews, assault, burglary, a spate of robberies sometimes laced with violence, pickpocketing cases, muggings, rapes, and even murders.

A major conclusion of the study was the myriad contingent of problems facing slum residents and slum youth in particular amongst others, the vicious cycle of poverty levels, the conundrum of poor education facilities, health services, unsanitary living environment, and the general morass of hopelessness in the slums of Nairobi which does not give the slum youth any escape to a better life.

The study concluded that women and children suffer most from criminal activities in the slums because of juvenile delinquency cases and youth unrests such as rapes and murders. The proliferation of illicit brews in the slums led to other social ills such as prostitution, a break-up of the family units, the spread of communicable diseases, and the increase in the number of single-parent households. Another conclusion was that the increase in the crime rates in the slums led to high mortalities among the youth in the slums, loss of lives of breadwinners in many households, loss of property by the slum residents and the general increase in lawlessness where the rules of the jungle prevailed, and the Darwinian principle of the survival of the very fittest was the order of the day. 


\section{RECOMMENDATIONS}

The study identified a cocktail of remedial measures geared towards tackling crime emanating from juvenile delinquency cases and youth unrest incidences in the slums of Nairobi, chief among them the need to encourage slum residents to come forward and be part of the solution to crime by being their brothers' keepers through community policing initiatives such as (Nyumba Kumi) ten households programme advocated by the Jubilee administration.

The efforts of the police through regular patrols in the crime hot spots, random visits into the slum areas, and the slum community engagement by the police were identified as possible remedial measures to crime due to juvenile delinquency and youth unrest.

The judiciary and the entire government system were encouraged by the study to support the slum residents and the police by jailing criminals who have been caught and convicted and not releasing them for flimsy reasons. The study findings concluded that there was the need to initiate crime prevention mechanisms such as police patrols, vigilante groups, employed night guards, village security committees, the use of gates and fences, among other measures.

\section{REFERENCES}

Kariuki-Githinji, S. Delinquency in Urban Kenya Secondary Schools: Implications for Parenting.

Muiya, B. M. (2014). The Nature, Challenges and Consequences of Urban Youth Unemployment: A Case of Nairobi City, Kenya. Universal journal of educational research, 2(7), 495-503.

Mwanjala, C. S. (2015). Determinants of juvenile involvement in criminal behaviour in TaitaTaveta County, Kenya (Doctoral dissertation, Kenyatta University).

Mwanza, M. M., Mwaeke, P., \& Omboto, J. (2020). Family Factors Influencing The Development Of Juvenile Delinquency Among Pupils In Kabete Rehabilitation School In Nairobi County, Kenya. Advances In Social Sciences Research Journal, 7(10). Retrieved From
Https://Drive.Google.Com/File/D/1rO1nce80etcxgqjjdpqn57pezpeuht9/View

Omboto, J. O., Ondiek, G. O., Odera, O., \& Ayugi, M. E. (2013). Factors influencing youth crime and juvenile delinquency. International Journal of Research in Social Sciences, 1(2), 18-21.

Rahman, M. (2015). Juvenile delinquency in the slum community: A study on Tejgaon area in Dhaka city (Doctoral dissertation, University of Dhaka).

Rahman, H. (2014). Juvenile Delinquency In The Slum Community: A Study On Tejgaon Area In Dhaka City. The University of Dhaka.

Riechi, B. (2019). Youth Unemployment and Security in Kenya: The Case of Kwale County (2010-2018) (Doctoral dissertation, United States International University-Africa).

RWENGO, Z. W. (2017). Factors influencing juvenile delinquency at Eldoret juvenile remand home, Kenya (Doctoral dissertation, MOI UNIVERSITY).

Thuku, H. N. (2017). Factors Contributing To Crime Among Juveniles: A Case Of Majengo, Rware Ward, Nyeri County, Kenya. Karatina University.

Wambugu, B. N., Njoroge, K. J., \& Komen, Z. (2013). Juvenile delinquency: A legacy of developmental logic of Kenyan Government.

Wanjeri, C. N. (2018). Psychological Interventions and their Effect on Behaviour Modification among Juvenile Delinquents: A Case of Eldoret and Kakamega Rehabs, Kenya. (Doctoral Dissertation, Kisii University).

37 | This work is licensed under a Creative Commons Attribution 4.0 International License. 